\title{
WHO launches World health report 2013
}

Eurosurveillance editorial team (eurosurveillance@ecdc.europa.eu) ${ }^{1}$

1. European Centre for Disease Prevention and Control (ECDC), Stockholm, Sweden

Citation style for this article:

Eurosurveillance editorial team. WHO launches World health report 2013. Euro Surveill. 2013;18(33):pii=20559. Available online: http://www.eurosurveillance.org/ ViewArticle.aspx?Articleld $=20559$

Article published on 15 August 2013

On 15 August 2013, the World Health Organization (WHO) launched the 'World health report 2013: Research for universal health coverage' [1]. The report addresses funding organisations, researchers (active and in the future) and policy makers. It shows how countries, when developing a system for universal health coverage, can use research to determine what health issues should be addressed, how a system should be structured and how to measure progress according to their specific health situation.

The report is divided in five chapters: Chapter 1 deals with the role of research for universal health coverage, for the provision of, and access to, high-quality health services; and financial risk protection for people who need to use these services. Chapter 2 gives an overview of the changing landscape of research while Chapter 3 presents examples of studies that show how research can address some of the major questions about achieving universal health coverage, and can deliver results that have influenced, or could influence, policy and health outcomes.
Chapter 4 describes the essential functions of national health research systems, namely: to set research priorities, to develop research capacity, to define norms and standards for research, and to translate evidence into practice. It presents mechanisms to stimulate and facilitate research for universal health coverage - monitoring (national and international observatories), coordination (information-sharing, collaborative research studies) and financing (raising and distributing funds to support global and national research priorities).

Chapter 5 proposes a set of actions by which the research community, national governments, donors, civil society and international organisations can support the research that is needed to reach universal health coverage.

\section{References}

1. World Health Organization (WHO): World health report 2013: Research for universal health coverage. Geneva: WHO. August 2013. Available from: http://apps.who.int/iris/ bitstream/10665/85761/2/9789240690837_eng.pdf 